\title{
ANI ÚMYSEL, ANI NÁHODA - SKÔR NIEČO MEDZI TÝM: POSTHUMANISTICKÉ TÉMY VO FILME EX MACHINA
}

IVAN LACKO, Katedra anglistiky a amerikanistiky, Filozofická fakulta Univerzity Komenského v Bratislave, Bratislava, SR

LACKO, I.: Not Random, Not Deliberate-Something In-Between: Posthumanist Themes in Ex Machina

FILOZOFIA, 75, 2020, No 2, pp. $148-157$

This article presents a posthumanist analysis of Alex Garland's 2014 movie Ex Machina with a specific focus on how the story, plot and style present posthumanist themes. The central issues discussed herein include the narrative and visual representation of the social and ethical questions related to the process of creating artificial intelligence with a humanoid appearance. The article discusses theses of posthumanism and posthumanization in the philosophical and aesthetic approach of the movie creators.

Keywords: Posthumanism - Posthumanization - Ex Machina - Jackson Pollock Turing test - Artificial intelligence

\section{Úvod}

Hoci téma uvažujúcich strojov, robotov, respektíve viacerých podkategórií toho, čomu hovoríme „umelá inteligencia“, je súčast’ou spoločenskej diskusie už dlho, práve technologický vývoj ostatných dvoch dekád priniesol širokospektrálnu reflexiu tohto fenoménu v akademickom svete, politike a umení. Posthumanistická spoločnost', v ktorej sa l'udia transformujú alebo fyzicky i intelektuálne prelínajú so strojmi, prípadne v ktorej existencia humanoidných tvorov (bytostí?) mení našu percepciu „ludskosti“, sa čoraz častejšie objavuje ako nosná téma rôznych žánrov literárnej, divadelnej a filmovej tvorby.

Tematika existencie rozumných strojov a komplikácie súvisiace $s$ ich vytvorením l’ud’mi dnes zdanlivo iba kopírujú líniu klasických príbehov - počnúc gréckou mytológiou (Prometeus) cez romantickú fascináciu súbojom človeka s prírodou (Frankenstein), technologické fóbie Karla Čapka, imagináciu Isaaca Asimova až po nespočetné postavy žánru sci-fi, ktoré približili robotov l’ud’om výzorom i správaním. Väššina diel pritom primárne vyjadrovala strach z málo známych a neprebádaných 
možností inteligentných strojov. Jedným z filozoficky najkomplexnejších filmov posledného obdobia je Ex Machina (2014) režiséra Alexa Garlanda, ktorý prináša do posthumanistického diskurzu viacero zaujímavých pohl'adov.

Ciel'om tejto štúdie je analýza filmu Ex Machina ako naratívneho a vizuálneho zobrazenia spoločenského a etického apelu pri vytváraní umelej inteligencie humanoidného vzhl’adu. Zámerom je ukázat' ako sú tézy posthumanizmu a posthumanizácie prítomné vo filozofickom a estetickom prístupe tvorcov filmu a zároveň načrtnút' možnosti filmového žánru komunikovat' otázky súvisiace s posthumanistickými témami efektívnejšie, ako to dokáže čisto filozofický diskurz. Ex Machina ponúka jedinečný pohl'ad na posthumanistickú budúcnost' v tom, že neprezentuje výhradne negativistickú perspektívu, v ktorej stroje ovládnu l'udstvo, ale ponúka komplexný pohl'ad na existenciu uvedomelých strojov - od záhady vzniku a fungovania ich vedomia cez túžbu po autonómnosti, slobode a slobodnej vôli až po úplnú l'ahostajnost' k l'udskej skúsenosti. Spôsob, ktorým Garlandov film tieto aspekty komunikuje, je vizuálne aj naratívne prispôsobený mnohovrstvovému charakteru zobrazovanej témy a rozvíja viaceré relevantné filozofické a spoločenské otázky.

\section{Posthumanizmus a premisa, podivnosti ${ }^{6}$}

Posthumanistickú spoločnost' okrem iných predznamenáva už Michel Foucault, ked' človeka nazýva relatívne mladým objektom, ktorý ako taký zrejme nebude mat’ dlhú trvácnost'. Foucault tvrdí, že ,je útechou, ked' si pomyslíme, že človek je iba nedávnym objavom, útvarom, ktorý nemá ani dvesto rokov, že je obyčajnou vráskou na tvári nášho poznania, ktoré sa stratí, akonáhle toto poznanie na seba vezme novú formu $(2005, \mathrm{xxv}) .{ }^{1}$ Ak je v nietzscheovskom ponímaní boh mítvy a pre Foucaulta sa l'udská identita formuje najmä prostredníctvom moci, priestor pre posun v chápaní l'udskej identity ako takej sa môže tvorit' aj transpozíciou na iné, posthumanistické podmienky. Uvažovanie o takýchto podmienkach prináša ideový rámec, $\mathrm{v}$ ktorom dochádza aj $\mathrm{k}$,posunu spoločenských, kultúrnych, politických a technologických dimenzií neskorej kapitalistickej, globalizovanej spoločnosti“ (Schmeink 2017, 40). Ide o variáciu ,antropocentrického obratu“, ktorý priniesla sekulárna éra, ked” sa jednotlivec začína vnímat' autonómne (Taylor 2007, 222). Slovami Stefana Herbrechtera ide o ,postantropocentrický pohl'ad“, v ktorom tkvie podstata posthumanizmu (2013, 2 - 3).

Proces posthumanizácie, ako o ňom hovorí napríklad Matthew E. Gladden, je súborom „dynamických javov, prostredníctvom ktorých spoločnost' prijíma členov odlišných od ,prirodzených“ biologických l'udských bytostí, ktoré rôznymi spôsobmi prispievajú do štruktúr, aktivít a zmyslu tejto spoločnosti“ $(2018,35)$. Preto treba te-

\footnotetext{
${ }^{1}$ Všetky preklady z anglických zdrojov sú autorove.
} 
oreticky predefinovat' vnímanie toho, čo označujeme za l'udské, respektíve humanistické, a to aj napriek tomu, že nie je jednoduché nové okolnosti jednoznačne uchopit'. Niektorí teoretici, napríklad Katherine Hayles sa nazdávajú, že najvhodnejší prístup je vedecké aspekty rozšírit' o príbehy súvisiace s posthumanistickým programom, pretože tie pomáhajú vytvorit' „viacvrstvový systém metaforických a hmotných prepojení, ktoré predefinujú pojmy ako ,život', ,príroda“ či ,l'udskost'““” $(1999,224)$.

V súvislosti s analýzou filmu Ex Machina je zaujímavý aj názor, že „úvahy o posthumanizácii l'udstva sa musia rozšririt' aj nad rámec kyborgizácie antropocentrického, individualistického, liberálneho humanizmu“ (Kim 2017, 410). Do posthumanistického diskurzu sa preto musí dostat' aj otázka koexistencie s bytost’ami, ktoré (zatial') inherentne nepokladáme za živé, respektíve za l'udské. Humanoidi v seriáloch Westworld alebo Humans, neodlíšitel'ní od živých l'udí, sú predpokladom na eliminovanie konceptu známeho ako uncanny valley, teda myšlienky rozvíjajúcej Freudov nepríjemný pocit podivnosti (unheimlich), ktorý aj v literárnom svete umožnil vnímanie doppelgängerov. ${ }^{2}$ Táto podivnost' je dimenziou, v ktorej sa ocitáme práve preto, že sme l'udia: „Byt' človekom znamená cítit' túto podivnost'. Vo svojich telách sa cítime prirodzene a neprirodzene zároveň. Vd’aka nášmu vedomiu sú nám naše vlastné črty zároveň dôverne známe a nepríjemne cudzie“ (Gray 2012, 31).

Bez existencie uvedeného pocitu podivnosti potom nastáva stieranie hraníc medzi živými l'ud’mi a ich robotickými kópiami, kyborgizovanými verziami alebo aj klonmi. To prispieva k ovel’a komplexnejšiemu vnímaniu obsahu a významu identity. Max More k tomuto diskurzu pridáva pozorovanie, že ,ked’že stále viac svojich spomienok si ukladáme externe a vytvárame avatary, je stále zrejmejšie, že hranice nášho ,ja' sa rozostrujú a nemusia byt' limitované na výskyt jedného tela“ $(2013,7)$. V dôsledku toho sme svedkami potreby nových (upravených) kultúrnych, filozofických a politických kategórií, ako aj definície iných ako l’udských kategórií bytostí. Andy Miah ukazuje zjavné prepojenie posthumanizmu s filozofiou a kultúrou a tvrdí, že hoci „filozofi sa tešili, že sa budú pomocou simulácie usilovat' porozumiet’ tomu, čo to znamená nebyt' človekom, kritici kultúry upriamovali pozornost’ na úlohu literatúry v procese vyhodnocovania tejto ambície“ (78). Percepcia posthumánneho subjektu je tak ovplyvňovaná dôsledkami ,čoraz častejšej interakcie medzi l’ud’mi a inteligentnými technológiami na jednej strane a stieraním rozdielov medzi l'ud'mi a inými druhmi na strane druhej“ (Tsimpuki 2017, 4).

\footnotetext{
${ }^{2}$ Doslovný preklad termínu uncanny valley, ktorý zaviedol Masahiko Mori, je bizarné / čudné / podivné údolie, teda pocit čudnosti, ktorý l'udia pocit’ujú pri pohl'ade na robota, ktorý vyzerá takmer, ale nie úplne, ako človek.
} 


\section{Alan Turing a Jackson Pollock}

Východiskovou myšlienkou filmu Ex Machina je otázka, ako sa autonómne uvažujúca umelá bytost' dokáže asimilovat' medzi l'udí a ako budú l'udia reagovat' na existenciu vnímavých, inteligentných a seba si uvedomujúcich bytostí. Na začiatku filmu protagonista Caleb vyhrá firemnú lotériu - týždňovú návštevu v odl'ahlom sídle zakladatel'a a generálneho riaditel'a korporácie Blue Book, tvorcu internetového vyhl'adávača, nie vel'mi odlišného od známeho giganta Google. Ked' sa Caleb zoznámi so šéfom firmy Nathanom, dozvedá sa, že sa má stat' l’udským komponentom v Turingovom teste stroja s umelou inteligenciou, ktorý Nathan vyrobil. ${ }^{3}$ Pôvodný test Alana Turinga bol zostavený tak, že testujúci mal sériou otázok určit', či komunikuje s človekom alebo strojom, pričom sa nachádzali v oddelených miestnostiach. Ak testujúci nevie rozlíšit, či komunikuje s človekom alebo počítačom, ,je to dostatočný dôvod na záver, že stroj dokáže mysliet”“ (Miah 2009, 78). Nathanova verzia testu však predpokladá, že jeho robot je taký vyspelý, že Calebovou úlohou bude zistit', či má vedomie, aj ked' testujúci na prvý pohl’ad vidí, že komunikuje so strojom.

A tak sa Caleb stretáva s Avou, humanoidným robotom, ktorého vzhl’ad je kombináciou elektroniky, svetielkujúcich obvodov a nerozpoznatel’ne l’udských čŕt. Caleb Nathanovi na rovinu povie, že vytvorenie takejto umelej inteligencie prekračuje vklad do dejín l'udstva, pretože sa tak píšu „dejiny bohov““. ${ }^{4} \mathrm{~V}$ tomto posthumanistickom kontexte Caleb skúšku Avinho sebauvedomenia prirovná k inšpekcii šachového programu, ktorý síce vie hrat' šach a poráža aj vel'majstrov, avšak neuvedomuje si, že hrá šach. Caleb svoju skúsenost' s Avou prirovná k metafore Lewisa Carrolla, ktorú známy americký autor vložil do názvu pokračovania svojho slávneho diela Alica $v$ krajine zázrakov - druhý diel sa v slovenskom preklade volá Za zrkadlom (a čo tam Alica videla). Pre Caleba sa totiž stretnutia s Avou nesú vo fantastickom, až magickom duchu tretieho zákona jedného z priekopníkov žánru sci-fi Arthura C. Clarka, ktorý hovorí, že ,akákol'vek dostatočne rozvinutá technológia je na nerozoznanie od mágie“ $(1977,1973,39)$.

Nathan Calebovi vysvetlí, ako sa dopracoval $\mathrm{k}$ takej vyspelej umelej inteligencii - ako CEO najväčšieho svetového vyhl'adávača online obsahu zozbieral údaje z kamier, mikrofónov a dátových úložísk všetkých mobilných telefónov na zemeguli (zrejme nie celkom legálne) a použil ich na generovanie mimiky, učenie jazyka a chápania súvislostí. Ava jednoducho dostala do výbavy celý internet vrátane dát o tom, ako sa l'udia správajú na sociálnych siet’ach. Nathan Avin mozog naplnil dátami zo

\footnotetext{
${ }^{3}$ Práve v roku 2015, takmer paralelne s uvedením filmu Ex Machina do kín, spoločnost' Google oznámila svoj zámer vyrábat' personalizovaných robotov (Lloyd 2015, 22).

${ }^{4}$ Všetky citáty z filmu Ex Machina uvádzam kvôli prehl'adnosti bez referencie - údaje k filmovému zdroju sú uvedené v použitej literatúre na konci textu.
} 
svojho vyhl'adávača: „Internetové vyhl'adávače nám nehovoria, čo si l’udia myslia, ale ako uvažujú - najprv príde impulz, potom reakcia; [1’udia uvažujú] premenlivo, nedokonale, raz schematicky, inokedy chaoticky." Ava sa tak stala nielen stelesnením typicky l'udského konania, ale aj reprezentáciou znepokojivého spôsobu použitia (zneužitia?) osobných údajov a dát všemožného druhu. To jej dáva l'udskost' a azda i vedomie, no popritom aj obrovskú moc.

Caleb je Avou fascinovaný a jeho úloha sa komplikuje - divák priamo vníma posthumanistický kontext definovaný partnerstvom medzi strojom a človekom, respektíve ich integráciou (Gladden 2019, 8). Caleb začína k Ave cítit' náklonnost', cíti, že ona s ním flirtuje, zatial' čo on zvažuje, do akej miery je tak naprogramovaná. Bizarné údolie, tá freudovská „podivnost“" pritom nie je spôsobená tým, že Ava by vyzerala takmer ako človek, naopak, jej robotickost' je priznaná od začiatku a Caleb má „čudný“ pocit práve preto, že ani to nestačí na to, aby mohol s určitost'ou povedat', že Ava je „iba“ stroj. Calebov zmätok ešte väčšmi podporujú rozhovory s Nathanom, ktorý mu vysvetlí, že skutočnou výzvou nie je automatickost' konania a správania Avy, ale simulácia jungovského nevedomia - ako v prípade abstraktného expresionizmu Jacksona Pollocka. Na príklade slávneho obrazu No. 5, 1948 Nathan vysvetlí, prečo neuznáva ani zámer, ani náhodu:

[Pollock] si úplne vyprázdnil mysel’ a dovolil rukám, aby robili, čo chcú. Nebolo to úmyselné, ale ani náhodné. Bolo to niečo medzi tým. Hovorí sa tomu automatické umenie. [...] Ale čo ak by Pollock ten postup obrátil? Čo ak by si namiesto tvorby umenia bez uvažovania povedal: „Viete čo? Nedokážem mal'ovat', ak nebudem vediet' presný dôvod, prečo malujem." Čo by sa stalo?

Caleb správne odpovie, že Pollock by potom nenamal'oval nič. Sám Pollock sa pri diskusii o akčnom umení $\mathrm{k}$ svojej špecifickej maliarskej technike vyjadril takto: „Dokážem ovládat' ako farba tečie, do istej miery, a nespolieham... nespolieham sa na náhody... pretože náhodu neuznávam“ (Karmel 1999, 22). Liminálny priestor medzi zámerom a náhodou, ktorý je pre Nathana predpokladom existencie seba si umelej inteligencie, ktorá si sama seba uvedomuje, je tak predpokladom humanoidnej umelej inteligencie.

\section{Sloboda, rovnost', bratstvo?}

Alan Turing do svojho opisu testu vedomia u strojov nezahrnul morálnu, respektíve etickú otázku o tom, čo môže nasledovat', ked' robot získa vedomie. Film Ex Machina túto otázku kladie ako centrálny problém, najmä v kontexte kontinuálnych zmien a nadobúdania identity, ktorý anglickým termínom perpetual becoming priliehavo 
označuje Miah $(2009,90) .{ }^{5}$ Dôležitost' komplexného chápania a akceptovania iných bytostí asi najexplicitnejšie prezentuje takzvaná Posthumanistická deklarácia, vypracovaná viacerými autormi v roku 2012:

Podporujeme blaho všetkých foriem vedomého vnímania vrátane l'udí, zvierat a akýchkol'vek budúcich foriem umelého intelektu, modifikovaných foriem života, ako aj inej inteligencie, ktoré môže priniest' technologický a vedecký po$\operatorname{krok}(2013,54)$.

Pre Nathana je Ava jednou z verzií umelej inteligencie, na ktorej pracuje. Skutočnost', že všetky verzie majú mená, tváre a telá však výrazne personalizuje celý proces vývoja. Úspešný test vedomého vnímania u Avy potvrdí nielen jej schopnost' manipulácie, zvádzania a egoizmu, ale aj pocit strachu mnohých l’udí z toho, že „posthumanizácia spôsobí, že l'udská rasa vyhynie" (Kim 2017, 396). Avu vidíme ako bytost', ktorej vedomé vnímanie je na takej vysokej úrovni, že jej primárnym ciel'om a motiváciou je uniknút' zo zajatia, do ktorého ju Nathan uvrhol tým, že ju vyrobil.

Ex Machina ukazuje možnosti spolužitia l'udí a vnímavých strojov - na jednej strane sa l'udia snažia pochopit' ako funguje vedomie u robotov, no na druhej strane zrejme mylne predpokladajú, že umelá inteligencia sa rovnako zaujíma o nás. Možno reálne predpokladat', že Ave na l'ud'och vel'mi nezáleží, ba že sú ,jej úplne ukradnutí“ (Robbins 2016). Nathan si však myslí, že jedného dňa sa inteligentné strojové bytosti budú pozerat' na l'udskú rasu ako na dajaký primitívny, nevyspelý kmeň, podobne ako sa my dnes pozeráme na skameneliny. $\mathrm{V}$ jednej $\mathrm{z}$ vrcholných scén filmu sa Ava Caleba pýta: „Čo sa stane, ak v tvojom teste zlyhám?“ Ked’ Caleb povie, že nevie a ani o tom nerozhoduje, Ava vyhŕkne logickú (ale emocionálne silnú) otázku: „Prečo by o tom mal vôbec niekto rozhodovat?"“

Problematika slobodnej vôle, prítomná vo väčšine naratívov o umelej inteligencii, sa tu dostáva do popredia najmä vd’aka utrpeniu ako spúšt’aču vedomia v strojovej inteligencii (seriály Westworld a Humans sú dobrými príkladmi). Vo filme Ex Machina však ide o skúsenost', ktorú na Avu prenáša najmä Caleb - pre jeho empatickost' si ho napokon Nathan vybral. Film pracuje s premisou, že diskusia o etických otázkach by mala zahíňat' chápanie, že „môžu existovat' rôzne úrovne kognitívneho poznania (v umelých i biologických formách), ktoré sú dostatočné na vnímanie utrpenia“" (Sorgner, Umbrello 2019, 4). Utrpenie je vo filme aj zo špecificky ženského uhla pohl'adu, ked'že Nathan Avu vytvoril aj ako sexuálny objekt. Catherine Constable

\footnotetext{
${ }^{5}$ Perpetual becoming znamená neustály, kontinuálny proces, v ktorom sa človek (alebo iná bytost') stáva niečím alebo niekým. Ide o proces nadobúdania identity.
} 
zaujímavo prezentuje jej „vnútorný priestor“ a telo ako systém znakov v zmysle argumentácie Judith Butlerovej o tom, ako môže telo navonok komunikovat' svoju „vnútornú híbku“ (2018, 287). Ked’ Caleb zistí ako „trpeli“ predchádzajúce Nathanove humanoidné roboty, začne aj Avu vnímat' ako „osobu“ práve cez jej „l'udskú schopnost' trpiet"“ (Constable 2018, 295). Inteligencia, improvizácia, utrpenie a slobodná vôl'a sú tak predpokladmi existencie vedome vnímajúcich strojových a človekom vyrobených bytostí, a to aj napriek diskurzu, ktorý niekedy spochybňuje existenciu vedomej slobodnej vôle aj u l'udí (Crompton 2015, 35).

\section{Za zrkadlom (krajina zázrakov)}

Ex Machina je komentárom, analýzou a sondou do kontextu procesu posthumanizácie. Nástroje na prezentovanie predmetného diskurzu sú pokusom o komplexnost', ktorý pripomína Avinu softvérovú výbavu, teda kontextuálne dokonalé poznanie všetkého. Toto funguje nielen $\mathrm{v}$ rovine alúzií a referenčného rámca filmu, ale aj v samom príbehu. V literárnom svete je už dlhšie známe organické, evolučnými teóriami ovplyvnené štruktúrovanie príbehov, ale aj predefinovanie významu l'udských postáv - Gillian Beer napríklad vo svojej rozprave o viktoriánskej próze tvrdí, že aj vd’aka Darwinovi sa ukázalo, že literárna zápletka, respektíve rozprávanie môžu existovat' aj bez človeka ako ústredného elementu $(2000,17)$.

Garlandov film je organicky komplexne vystavaný a jednotlivé referencie sú zosiet'ované tak, aby odkazovali na tému posthumanizmu, no zároveň aj na to, aké problematické môže byt' narábat's takou rozsiahlou databázou vel'mi heterogénnych údajov. Sám názov Ex Machina odkazuje na pojem deus ex machina v gréckej dráme, pričom boh sa tu zo známej formulky vytráca a otázka znie, čo vlastne príde zo stroja, ak nie nadpozemský prvok, ktorý všetko vyrieši. Caleb a Nathan sú alúziami - na biblického Kaleba, ktorý bol zvedom, a proroka Nátana - a aj meno Ava je odkazom na biblickú Evu. Híbka referencie je pritom jasná, najmä s prihliadnutím na spomínaný postantropocentrický posun: Ava neposlúchne, ale nie Boha, ale svojho stvoritel'a, a z „raja“" sa vyženie sama.

Calebovo prirovnanie interakcie s Avou k Alicinej skúsenosti z príbehu Za zrkadlom metaforizuje celý Nathanov rezidenčný komplex plný skiel a zrkadlových odrazov na vizuálnu reprezentáciu neistoty, čo je pravé, a čo je reflexia či kópia. Vo väčšine scén nevidíme len tváre protagonistov $\mathrm{v}$ priamych záberoch, ale aj ich odrazy v skle / zrkadle, niekedy verné, inokedy pokrivené. Vizuály naznačujú duálnost' nášho vnímania, ale aj duálnost' existencie ako takej - čo vyvrcholí v scéne, ked' Ava kladie Calebovi otázky a s presnost'ou dokonalého detektora lži ihned' odhalí, či hovorí pravdu. Strach z iného (či dokonca inakosti?), ono sartrovské peklo, ktoré tvoria iní l'udia, sa v uzavretých priestoroch Nathanovej firmy stáva funkčným elementom, 
ktorý posilňuje vzájomnú nedôveru, a paradoxne aj Calebovu naivnú vieru v Avinu empatickost'.

Zaujímavým estetickým elementom je aj použitie farieb - napríklad modrej. Tá oznamuje, že inak zamknuté dvere sú otvorené, no objavuje sa aj v názve firmy Blue Book, explicitne odkazujúc na Ludwiga Wittgensteina a jeho Modrú a hnedú knihu. Nathanova zbierka nefunkčných tiel modelov robotov v skriniach pripomína strašidelný príbeh Modrofúza a jeho mótve ženy. Dusivá červená pri výpadkoch prúdu zámerne kontrastuje s krištálovo čistými zábermi z exteriérov na rozl'ahlé zelené hory a lesy. Ked' Caleb Ave spomenie experiment s názvom Mary v čiernobielej izbe, v ktorom vedkyňa Mary študujúca farby žije $\mathrm{v}$ čiernobielej izbe, a tak prichádza o zážitok z farieb, o ktorých inak teoreticky všetko vie, Ava reaguje emocionálne, pretože si okamžite urobí paralelu s vlastnou existenciou.

Komplexnost' referenčného rámca filmu je zjavná aj v načrtnutí témy virtuálnosti l'udského života, podobne ako to robí známa filmová trilógia Matrix. Film rozvíja aj diskusiu o pravosti vnímania a poznania, vychádzajúcu z metafory Platónovej jaskyne, a odkazuje na klasické diela literatúry, napríklad na poviedku Der Sandmann E. T. A. Hoffmanna o vzt'ahu protagonistu k umelej bytosti, či na túžbu bábky Pinocchia stat' sa človekom. V záverečnej scéne filmu sa Ava dokonca usmieva a prejavuje radost' z nadobudnutej slobody, ked' schádza po schodisku a opúšt’a dom, v ktorom strávila celú doterajšiu existenciu. Vtedy opät' pripomína Carrollovu Alicu, ktorá chce vidiet' zvyšok domu, kým sa nebude musiet' vrátit' cez zrkadlo domov, a zdá sa, akoby sa vznášala nad zábradlím schodiska (1909, 18 - 19). Takéto zosiet’ovanie kultúrnych referencií a alúzií je, okrem špeciálnych efektov, silným nástrojom na prezentovanie liminálnych filozofických myšlienok, ktoré by možno striktne akademickému prístupu chýbali.

\section{Z pešiaka král'ovná? - posthumanistická realita}

Ex Machina prezentuje svet ned’alekej budúcnosti, v ktorom nerezonuje otázka, či sa budeme musiet' naučit' spolunaživat's humanoidnými formami umelej inteligencie, ale ako sa s touto skutočnost'ou vyrovnáme. Ako hovorí Ray Kurzweil, ,istá čast' reality budúcnosti môže byt' neodvratná, ale ked’že sa zatial' neprejavila, l'ahko sa nám odmieta“ $(2005,192)$. Na záver filmu sa Ava, už medzi l'ud'mi a d’aleko od svojho stvoritel'a, pozerá cez carrollovské zrkadlo a divák uvažuje, či sa rovnako ako fiktívna Alica na konci cesty po šachovom poli zmení z pešiaka na královnú. Respektíve, či sa potvrdia opakované odkazy na Roberta Oppenheimera a či Avina budúcnost' nebude pre l'udstvo rovnako hrozivá ako bezhraničná sila jadrovej energie. V podobnom duchu film pripomína, že umelej inteligencii, ktorá si uvedomuje svoju existenciu a zároveň disponuje obrovským logickým a racionálnym potenciálom, môžu hrozit’ aj 
„najrôznejšie mentálne poruchy“, pretože ak predpokladáme, že existuje „mysel’, ktorá dokáže zmenit' spôsob svojho fungovania, rovnako sa môže aj sama zničit““ (Minsky 2006, 341).

Ďalší príbeh Avy je na konci filmu otvorený, pretože spoločnost' novej generácie fungujúca na posthumanistickom základe môže priniest' rovnako „vylepšenia, ale aj rozruch“ (Gladden 2019, 4). Ex Machina ukazuje, ako mnohí umelo vytvorení členovia takejto spoločnosti nebudú môct' byt' nad’alej vnímaní iba ako „pasívne ,nástroje“ či anonymné súčasti prostredia," ale možno ako plnohodnotní účastníci spoločenských, kultúrnych a politických procesov (Gladden 2019, 5). Záver filmu a jeho filozofický odkaz sú tak reflexiou liminálnosti, zdôraznením dôležitosti „niečoho medzi tým“ v aktuálnom diskurze o posthumánnej spoločnosti.

\section{Literatúra}

BEER, G. (2000): Darwin's Plots. Evolutionary Narrative in Darwin, George Eliot and Nineteenthcentury Fiction. Cambridge: Cambridge University Press.

CARROLL, L. (1909): Through the Looking-glass. And What Alice Found There. New York: Dodge Publishing Company.

CLARKE, A. C. (1977, 1973): Profiles of the Future. An Inquiry into the Limits of the Possible. New York: Popular Library.

CONSTABLE, C. (2018): Surfaces of Science Fiction. Enacting Gender and "Humanness" in Ex Machina. Film-Philosophy, 22 (2), 281 - 301. DOI: https://www.euppublishing.com/ doi/10.3366/ film.2018.0077

CROMPTON, S. (2015): Free Will. The Greatest Illusion. Focus: Science and Technology, June $2015(281), 32-39$.

FOUCAULT, M. (2005): The Order of Things. An Archaeology of the Human Sciences. LondonNew York: Routledge (Routledge classics).

GARLAND, A. (2014): Ex Machina. Universal Pictures International.

GLADDEN, M. E. (2018): A Typology of Posthumanism. A Framework for Differentiating Analytic, Synthetic, Theoretical, and Practical Posthumanisms. Indianapolis: Defragmenter Media.

GLADDEN, M. E. (2019): Who Will Be the Members of Society 5.0? Towards an Anthropology of Technologically Posthumanized Future Societies. Social Sciences 8 (5), 1 - 39. DOI: 10.3390/socsci8050148

GRAY, C. H. (2012): Cyborging the Posthuman. Participatory Evolution. In: Kasper LippertRasmussen - Mads Rosendahl Thomsen - Jacob Wamberg (eds.): The Posthuman Condition. Ethics, Aesthetics and Politics of Biotechnological Challenges. Aarhus: Aarhus University Press, $27-39$.

HAYLES, K. (1999): How We Became Posthuman. Virtual Bodies in Cybernetics, Literature, and Informatics. Chicago, London: University of Chicago Press.

HERBRECHTER, S. (2013): Posthumanism. A Critical Analysis. London: Bloomsbury.

KARMEL, P. (ed.) (1999): Jackson Pollock. Interviews, Articles, and Reviews. New York: Museum of Modern Art; H. N. Abrams.

KIM, J. (2017): Transindividual-Transversal Subjectivity for the Posthuman Society. Kriterion: Revista de Filosofia, (58), 391 - 411. DOI: 10.1590/0100-512X2017n13709jhk

KURZWEIL, R. (2005): The Singularity is Near. When Humans Transcend Biology. New York: Viking.

LLOYD, J. (2015): Affable Robots. Focus: Science and Technology, June 2015 (281), 22. 
MIAH, A. (2009): A Critical History of Posthumanism. In: Bert Gordijn - Ruth Chadwick (eds.): Medical Enhancement and Posthumanity, Vol. 2. Dordrecht: Springer Netherlands, 71 - 94.

MINSKY, M. (2006): The Emotion Machine. Common Sense Thinking, Artificial Intelligence, and the Future of the Human Mind. New York, London: Simon \& Schuster.

MORE, M. (2013): The Philosophy of Transhumanism. In: Max More - Natasha Vita-More (eds.): The Transhumanist Reader. Classical and Contemporary Essays on the Science, Technology, and Philosophy of the Human Future. Chichester, West Sussex, UK: Wiley-Blackwell, 3 - 17.

ROBBINS, M. (2016): Artificial Intelligence. Gods, Egos and Ex Machina. The Guardian 1 (26) Dostupné na: https://www.theguardian.com/science/the-lay-scientist/2016/jan/26/ artificial-intelligence-gods-egos-and-ex-machina (Dátum návštevy: 30. 5. 2019).

SCHMEINK, L. (2017): Biopunk Dystopias. Genetic Engineering, Society and Science Fiction. Liverpool - Berlin: Liverpool University Press.

SORGNER, S. L., UMBRELLO, S. (2019): Nonconscious Cognitive Suffering. Considering Suffering Risks of Embodied Artificial Intelligence. Philosophies, 4 (24), 1 - 15. DOI: https://doi.org/10.3390/philosophies4020024

TAYLOR, C. (2007): A Secular Age. Cambridge, Mass., London: Belknap.

TSIMPUKI, T. (2017): War on the Human. Always Already Posthuman or Not Quite Human Yet? In: Theodora Tsimpouki - Konstantinos Blatanis - Rachele Dini (eds.): War on the Human. New Responses to an Ever-present Debate. Newcastle upon Tyne: Cambridge Scholars Publishing, $1-29$.

VIACERÍ AUTORI (2013): Transhumanist Declaration (2012). In: Max More - Natasha Vita-More (eds.): The Transhumanist Reader. Classical and Contemporary Essays on the Science, Technology, and Philosophy of the Human Future. Chichester, West Sussex, UK: Wiley-Blackwell, $53-55$.

Táto štúdia vznikla na Katedre anglistiky a amerikanistiky FiF UK v Bratislave a bola podporená Agentúrou na podporu výskumu a vývoja na základe Zmluvy č. APVV-17-0064.

Ivan Lacko

Katedra anglistiky a amerikanistiky

Filozofická fakulta Univerzity Komenského

Gondova 2

81499 Bratislava

Slovenská republika

email: ivan.lacko@uniba.sk

ORCID ID: https://orcid.org/0000-0003-3494-3990 